\title{
MEDAILONOVÉ KACHLE Z JAVORNÍKA
}

\author{
MARKÉTA TYMONOVÁ
}

Abstrakt: Přispěvek se zabývá souborem renesančních medailonových kachlů nalezených v letech 19961997 v zásypu tzv. vlči jámy pod branskou věži zámku Jánský Vrch v Javorníku. Jde o kolekci kamnářských výrobků vyrobených v habánském stylu, které byly součástí kamen otápějících místnosti biskupského sídla kolem poloviny 16. století.

Klíčová slova: kachlová kamna - medailonové kachle-zámek Jánský Vrch v Javorníku.

\section{Medallion Tiles from Javornik}

Abstract: This contribution discusses a series of renaissance medallion tiles uncovered in 1996-1997 in the fill of the "wolf pit" under the gateway tower of the Jánský Vrch castle in the town of Javornik. The series comprises stove products made in the Anabaptist style that were parts of stoves heating the rooms in the bishop's castle around the mid-16th century.

Key words: tile stove - medallion tiles - Jánský Vrch castle, Javornik.

\section{Úvod}

Torzální architektura představuje jeden z poměrně častých archeologických nálezů z období středověku a raného novověku, který dokládá stavební vývoj objektu v určitém sociálním prostředí. Zpravidla jde o pozůstatky profánních nebo sakrálních staveb, dříve užívaných aristokracií, měštanstvem, církevními institucemi nebo př́íslušníky vesnických komunit $\mathrm{k}$ sídelním, hospodářským nebo kultovním účelům. Jejich využití naznačuje nejen celková dispozice a umístění v terénu, ale i pozůstatky interiérového vybavení, jež zpravidla slohově konvenovalo s ostatní architekturou. Neoddělitelnou součást nálezových kontextů s vysokou vypovídací hodnotou tvoří hmotný inventáŕ, jenž informuje o každodenním životě a životním stylu obyvatel daného sídla.

Movité památky, dokladující aktivity hmotné i duchovní povahy, přispívají k poznání dynamiky proměn v oblasti kultury bydlení, jež odvisela od majetnosti a sociálního zařazení jedince ve společnosti. Úroveň vnitřního vybavení podléhala působení celé řady faktorů, motivovaných snahou prezentovat privilegované postavení, rodovou prestiž, zastávanou funkci nebo náboženské vyznání, které bývaly symbolicky zhmotněny nejen v sochařské a malířské výzdobě, ale také v ikonografii kachlových kamen, která představovala nejnákladnější kus interiérové výbavy. Tento z hlediska provozu vysoce efektivní a zároveň i bezpečný zdroj tepla, spojující účelnost s estetickou funkcí, limitovala řada faktorů. Kromě omezené fyzické životnosti ovlivňovaly délku používání technologické inovace zaměřené na ekonomiku provozu a také slohové trendy, spojené s estetickou stránkou výtvarného pojetí reliéfní výzdoby. K výměně funkčně či vzhledově nevyhovujícího otopného zařízení většinou docházelo během stavebních úprav realizovaných za účelem pohodlnějšího bydlení. Při zařizování obytných prostor hrály důležitou roli stále se zvyšující nároky na komfortní vybavení, jehož neodmyslitelnou součástí bylo efektivní bezdýmné vytápění v kachlových kamnech, která na rozdíl od krbů místnost př́ijemně vyhřála a zároveň v ní teplo déle udržela.

Když otopné zařízení z důvodů technických či estetických dosloužilo, bylo vyměněno za nové. Se sutí ze zbořeného tělesa obsahující zbytky kachlů a kamnářské mazanice se zacházelo stejně jako s ostatním nepotřebným odpadem: ve městech se sypala do jímek a městských příkopů nebo se vyvážela na komunální smetiště. Na panských sídlech se vysypávala všude tam, kde to bylo možné - do hradních příkopů či zahloubených nefunkčních prostor, což doložila situace na zámku Jánský Vrch v Javorníku, kde demolice vyplnila nefunkční vlčí jámu pod branskou věží na severovýchodní straně objektu. Nebylo-li zbytí, odpad se vysypal mimo areál na svah 
pod zámkem, jak dokládají nálezy kachlů pod Eichendorfovou vyhlídkou, anebo posloužil k vyrovnání terénních nerovností, což ukázala situace na jižní straně východního předhradí.

\section{Dějiny hradu a historické souvislosti}

Javornické sídlo, z jehož areálu pochází několik různě starých kachlových souborů, stojí na skalnaté ostrožně nad údolím Jánského a Račího potoka v severovýchodní části Rychlebských hor, které vytváří přirozenou hranici se sousedním polským územím (obr. 1). Ves téhož jména byla poprvé zmíněna $\mathrm{v}$ roce $1290 \mathrm{v}$ soupise majetků vratislavského biskupství, ale sám hrad je písemně doložen až roku 1307 v listině braniborského markraběte Heřmana, v níž se jmenuje kastelán Richolf jako správce svídnického vévody Bolka I. († 1301), jemuž se podařilo ovládnout jihozápadní část niského knížectví. Tato řídce osídlená oblast v javornickém výběžku byla původně součástí otmuchovské kastelánie, jmenované prvně roku 1155 v bule papeže Hadriána IV., k níž v roce 1199 opolský kníže Jaroslav připojil niskou část (Zuber 1972, 29; Kouřil-PrixWihoda 1997, 111; 2000, 439, 445; Kouřil-Wihoda 2001, 206; Chrobak-Szymkowicz 2007, 7, 13; Vojkovský 2008, 3; Tymonová 2011, 89).

Na kolonizaci tohoto pohraničního území se kromě světské moci podílelo také vratislavské biskupství, jehož aktivity vyvolaly řadu mocenských střetů, které vyvrcholily zabráním Zlatohorska moravským markrabětem Vladislavem Jindřichem (Wihoda 1998, 24). Neshody moti-

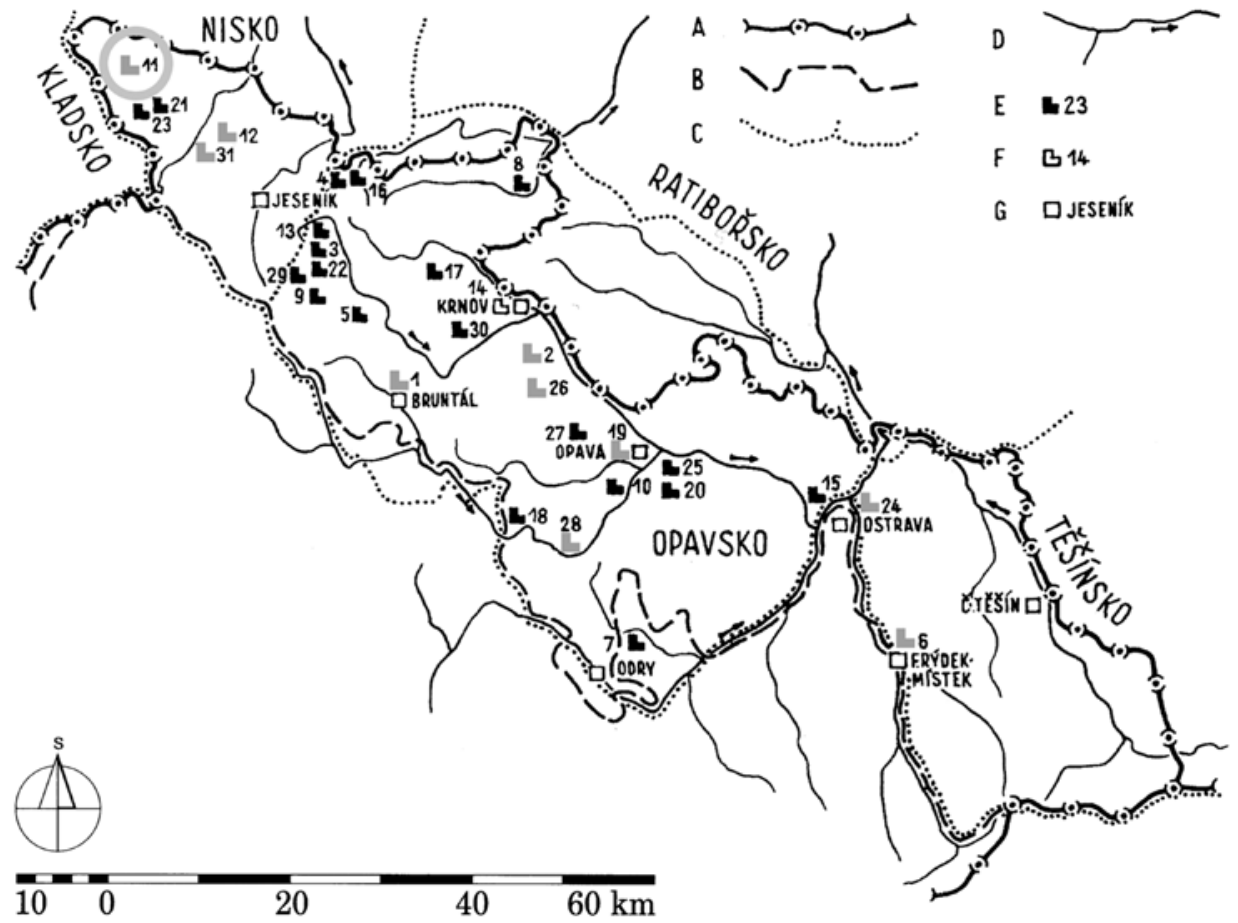

Obr. 1. Javorník - Jánský Vrch: Mapa hradů českého Slezska s šedě vyznačenými lokalitami s nálezy kachlů. 1 - Bruntál, 2 - Cvilín, 6 - Frýdek, 10 - Hradec u Opavy, 11 - Javorník, 12 - Kaltenštejn, 24 - Slezská Ostrava, 26 - Vartnov, 28 - Vikštejn, 31 - Žulová; A - dnešní státní hranice, B - historická hranice Čech, Moravy a Slezska, C - hranice středověkých knížectví, D - vodní toky, E - hrad, F - městský hrad, G - orientační body. Podle Kouřil-Prix-Wihoda 2000, 15, upraveno.

Abb. 1. Javorník - Johannesberg. Karte mit den Burgen in Tschechisch-Schlesien und den rot gekennzeichneten Fundstellen der Kachelfunde. 1 - Bruntál, 2 - Cvilín, 6 - Frýdek, 10 - Hradec u Opavy, 11 - Javorník, 12 - Kaltenštejn, 24 - Slezská Ostrava, 26 - Vartnov, 28 - Vikštejn, 31 - Žulová; A - heutige Staatsgrenze, B - historische Grenze von Böhmen, Mähren und Schlesien, C - Grenze der mittelalterlichen Fürstentümer, D - Wasserläufe, E - Burg, F - Stadtburg, G - Orientierungspunkte. Nach KouřilPrix-Wihoda 2000, 15, bearbeitet. 
vované snahou udržet území kolem Otmuchova jako nezávislou církevní državu pokračovaly za knížete Jindřicha IV. Proba († 1290), jenž obsadil hrad Edelštejn se Zlatými Horami (Zuber, 1966, 72). Rozbroje neustaly ani za biskupa Přeclava z Pogarel († 1376), který postoupil Javorník svídnickému vévodovi Bolkovi II. († 1368). Po jeho skonu se hradu zmocnil nemodlínský kníže Jindřich, avšak okamžitý zásah papežské stolice v roce 1371 tyto separační tendence zmařil a javornické zboží se opět vrátilo k mensálním statkům (Kubešová-Richterová 1999, 58; Kouřil-Prix-Wihoda 2000, 445; Vojkovský 2008, 4).

Za husitských válek v roce 1428 Javorník spolu s Otmuchovem a Pačkovem dobyli kališníci, a když jej po šesti letech vratislavská kapitula opět ovládla, z obavy, aby nepadl do nepřátelských rukou, nechal jej Konrád z Olešnice pobořit, jelikož biskupství nemělo prostředky na vydržování stálé posádky. O tři roky později je v pramenech uváděn jako pustý (Kouřil 2009, 221-222; Dehnerová-Šlézar 2012,4) a po odeznění válečných nepokojů byl pronajímán různým šlechticům (1435: Pelkan z Kalkova, 1441: Zikmund z Rachnova, 1445: Jan Swittling [Světlík], 1464: biskupský maršálek Nickel Streit; Kubešová-Richterová 1999, 59). Od roku 1474, kdy se dostal opět pod přímou biskupskou správu, byl už tak zdevastovaný, že jej biskupové Jan Roth (1482-1506) a Jan Thurso (1506-1520) nechali zrenovovat a přestavěli ho na renesanční zámek, nazvaný na počest patrona biskupské stolice sv. Jana Křtitele „Jánský Vrch“ („Johannisberg“). V roce 1497 koupil jesenickou část dominia rod Fuggerů, aby v kraji financoval dobývání drahých kovů. Když se však očekávané výtěžky nedostavily, augsburští podnikatelé doly prodali zpět Baltazaru z Promnic (1539-1562), který, podobně jako jeho nástupce Kašpar z Lohova (1562-1574), v těžbě pokračoval kvůli potřebě kovu k ražbě zlatých mincí.

Na počátku třicetileté války bylo Javornicko, Jesenicko a Nisko obsazeno protestantskými vojsky Jana Jiř́iho Krnovského, před nímž musel biskup Karel Josef Habsburský († 1664) roku 1620 uprchnout do Krakova. Po roce se sice vrátil, ale jeho náhlé úmrtí uvolnilo místo teprve dvanáctiletému synovi polského krále Zikmunda III. Karlu Ferdinandovi (Fukala 1997, 95; 2005, 92, 154, 168; Vojkovský 2008, 10). Později zámek i město několikrát vydrancovali Dánové (1626), Sasové $(1633)$ a Švédové $(1639,1646)$ a uklidnění poměrů nastalo až za císařova syna biskupa Leopolda Viléma (1656-1662), jenž do úřadu nastoupil v roce 1656. Zásadní změnu státoprávního uspořádání pak přinesly slezské války (1740-1748), kdy se část Slezska od roku 1742 připojila k Prusku a Javornicko se jako součást rakouské části niského knížectví ocitlo na samé periferii habsburské monarchie. Oživení do Javorníka přinesl až příchod bývalého exponenta pruského krále Bedřicha biskupa Filipa Gotharda Schaffgotsche († 1795), jenž se na Jánském Vrchu usadil v roce 1776 po předchozí internaci ve františkánském klášteře v Opolí (Settari 1993, 47; Vítek 2010, 216).

\section{Vývoj stavební dispozice}

Současná podoba hradu zachycující stav po pozdně barokních přestavbách za biskupa Schaffgotsche v zásadě respektuje pozdně gotickou protáhlou dispozici přibližně trojúhelníkového půdorysu, vymezenou na severu obvodovou hradbou s oblou baštou a protilehlým válcovým bergfritem (průměr $9,9 \mathrm{~m}$ ), překrytým od úrovně prvního patra palácovou budovou.

Výraznější proměny objektu způsobila pozdně gotická přestavba provedená v letech 1482 1509 za pontifikátu Jana Rotha (1482-1506) a Jana Thursy (1506-1520), jež rozdělila půdorys na dvě výškově odstupňované části - severně položený „dolní“ hrad s dělostřeleckou baštou, přestavěnou na hradní kapli, a „horni““ hrad s gotickým palácem na východní straně nádvoří. Modernizace se zaměřila na obranný systém s flankovacími věžicemi, vstupní komplex s branskou věží a starý palác, spojený s bergfritem patrovým traktem. O rozsáhlých stavebních úpravách informují dvě dedikační desky: první z roku 1506 s klečícím donátorem, považovaná za nejstarší doklad renesance v českém Slezsku, je druhotně osazena na východní straně nádvoří; druhá z roku $1509 \mathrm{~s}$ thursovským rodovým erbem visí nad průjezdem do horního hradu (KouřilPrix-Wihoda 2000, 204; Vítek 2009; 2010, 215; Myslivečková 2011, 37-38). V úpravách interiérů pokračovali i Thursovi nástupci Jakub ze Salzy a Kašpar z Lohova, za nichž se na Javornicku 
šířilo protestantství. Následné pozdně renesanční přestavby inicioval biskup Karel Habsburský v letech 1616-1617, kdy byl na dolním hradě postaven nový palác s kaplí v přízemí a arkádou v prvním patře.

Stavební aktivity poměrně dobře mapují dendrochronologické analýzy, které posunují dokončení thursovské přestavby za rok 1509, protože vzorky dřev z koruny branské budovy poskytly data 1515 a 1525 a zastřešený ochoz spojovací chodby mezi horním a dolním hradem časový interval let 1512-1514. Aktivity Karla Habsburského určily vzorky odebrané z krovů paláce na dolním hradě, $\mathrm{k}$ jejichž stavbě bylo použito dřevo ze stromů skácených v roce 1616 (Kašpárková-Peřinová-Vítek 1995, 197; Kouřil-Prix-Wihoda 2000, 203-204; Vítek 2010, 213). Podobně byly při stavebně historickém průzkumu v roce 1995 využity výsledky rozborů omítek, na jejichž základě byly rozlišeny dvě fáze pozdně barokních přestaveb: první z let 1766-1767 se dotkla objektů na nádvoří dolního hradu a branské budovy; druhá se uskutečnila v 70. letech 18. století, kdy byl snížen bergfrit a zbudováno jižní křídlo s reprezentačními prostory (Vítek 2010, 216).

\section{Nálezové okolnosti}

Archeologický výzkum zámeckého areálu, při němž byly získány i dva kachlové soubory, prováděli za odborného dohledu Pavla Kouřila z brněnského Archeologického ústavu pracovníci Vlastivědného muzea v Jeseníku Zdeněk Brachtl (1995-1997) a Milan Rychlý (1999-2000), v té době ještě pracovník zámku. Třetí vyzvedl Pavel Šlézar (2002) z olomouckého pracoviště tehdejšího Státního památkového ústavu (dnes Národního památkového ústavu, ú. o. p. v Olomouci), pod jehož správu Jánský Vrch v současnosti spadá (obr. 2).

Výkopové práce vedené Zdeňkem Brachtlem inicioval stavebně historický průzkum, během něhož bylo položeno celkem jedenáct zjištovacích sond. Kachle s medailony obsahoval zásyp sondy č. IX/96 (2,7×4,2 m, hloubka 4,3-5 m), položené v prostoru tzv. vlčí jámy u původního vstupu pod branskou věží na severovýchodní straně, jejíž vnější část vystupující před bránu

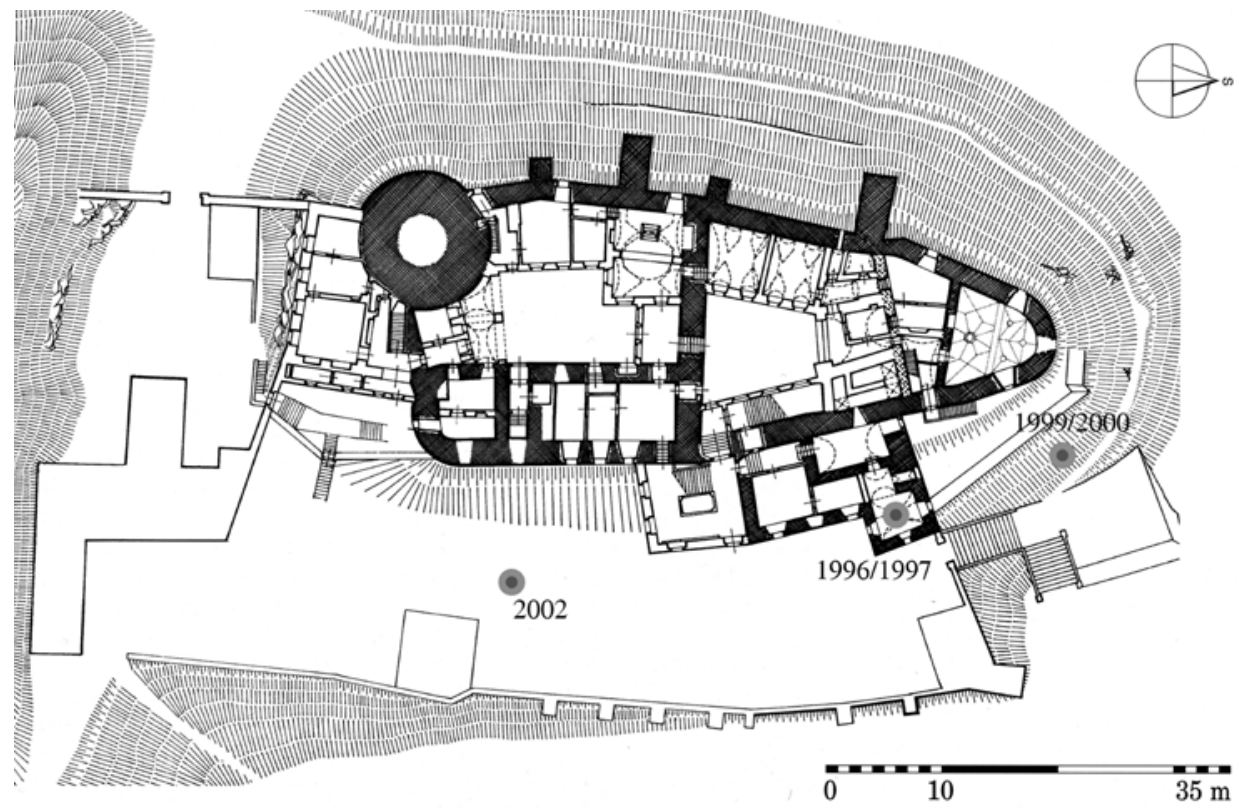

Obr. 2. Javorník - Jánský Vrch. Půdorys javornického hradu s místy nálezů kachlů. Podle Kouřil-Prix-Wihoda 2000, 202, upraveno. Abb. 2. Javorník - Johannesberg. Grundriss von Burg Javorník mit gekennzeichneten Kachelfunden. Nach Kouřil-Prix-Wihoda 2000,202 , bearbeitet. 
zachytil v roce 2002 Pavel Šlézar (Vítek 2010, 213). Z jednorázového zásypu byly kromě kachlů vyzvednuty také dvě mince a fragmenty stř̌edověké a raně novověké keramiky (většina $z 15$. století) spolu s železnými předměty (Brachtl 1997, 202; 1997a, 127-128; 1998, 134-136; 1998a, 93; 1999, 407-408; 1999a, 328-329; 2000, 159-161; Kouřil-Prix-Wihoda 2000, 206; Rychlý 2003, 45-46; Tymonová 2011, 92; Dehnerová-Šlézar 2012, 5, 10).

Druhý kachlový soubor zachránil v roce 1999 Milan Rychlý při rekonstrukci kanalizace pod Eichendorfovou vyhlídkou. Další záchranné práce, vyvolané v roce 2001 sesuvy půdy u severní flankovací věže, přinesly převážně kovový a keramický materiál z období dobytí hradu husity (Rychlý 1999, 92; 2000, 29-30; 2003 45-46; Rychlý-Kolář 2002, 44-45; Kouřil 2009, 221-222; Tymonová 2011, 92; Dehnerová-Šlézar 2012, 5, 11).

Třetí soubor objevil v roce 2002 Pavel Šlézar při dostavbě kanalizační sítě ve východní části předhradí, kde ve výkopu jižní části sondy S7/02, položené na místě bývalého šíjového př́ikopu, narazil na požárovou vrstvu s fragmenty pozdně gotických kachlů a keramikou z průběhu 15. století. Evidentně šlo o další zbytky kamen, jejichž destrukce posloužila k vyrovnání terénu v době přestaveb na přelomu 15. a 16. století (Šlézar 2003, 255; Dehnerová 2011, 29-31; Dehnerová-Šlézar 2012, 5, 11).

\section{Medailonové kachle a ostatní kachlový materiál}

Kachle vyzvednuté Zdeňkem Brachtlem v srpnu 1996 a červenci 1997 ze zaniklé vlčí jámy sestávaly až na jeden nádobkový exemplář se čtvercovým ústím z řádkových nebo korunních kusů se stopami použití v podobě sazovitých povlaků a zbytků kamnářské mazanice na vnitřních stranách komor. Protože řada z nich již byla publikována, jen stručně připomeňme, že šlo o dva časově dobře odlišitelné celky. Starší zastupovaly pozdně gotické kusy s vysokými kuželovými nebo půlválcovými komorami z konce 15. a počátku 16. století s motivy náboženskými: Panna Marie - zbožná matka a prorok Daniel (naposledy Mazur 2014, 186-187, 192-193, Ryc. 2:1-12); heraldickými: prázdný štít; ornamentálními: násobná pětilistá rozeta a architektonickými: pyramidovitě uspořádané korunní nástavce s široce rozestoupeným písmenem „M“, připomínajícím obrácený vladislavský emblém (Brachtl 1999b, 128-131; Tymonová 2009). Do mladší kolekce z první poloviny 16 . století se čtvercovou čelní vyhřívací stěnou (dále jen ČVS) a mírně kónickými komorami (hloubka $100 \mathrm{~mm}$ ) náležely kachle s portrétními motivy: portréty urozených mužů (2) a ženy (1) v renesančních šatech pod arkádou (Brachtl 1999b, kat. č. 132-134; naposledy Mackiewicz 2013, 444-445).

Třetí skupinu, která se od předchozích odlišovala po stránce technologické, morfologické i výzdobné, tvořily medailonové kachle, jež se u nás prvně objevují kolem poloviny 16 . století v prostředí moravských habánských dílen. Tyto výrobky z materiálu ostřeného hrubším pískem, vypáleného do červených a šedohnědých tónů zastupovalo pět částečně i úplně zachovalých kusů s centrálně umístěnými konvexními (vypouklými) a konkávními (vydutými) miskami uprostřed čtvercových ČVS, které byly spojeny s komorou výrazným vějířovitým prstováním po obvodu. Na rozdíl od jiných raně novověkých tvarů s rámovou komorou a čtyřhranným vyhřívacím otvorem měly javornické exempláře komoru válcovou s pláštěm opatřeným obvodovými žlábky a záchytnými otvory, ukončenou kruhovým vyhřívacím otvorem s rovně seříznutým, prstencovitě zduřelým okrajem. Rubové strany ČVS obou variant nesly jemné otisky textilie s mělkými prohlubněmi po zamačkávání do matrice, avšak jejich výzdoba a povrchová úprava byla rozdílná. Konvexní, vyskytující se $\mathrm{v}$ řádkové i rohové variantě, měly vypouklý medailon orámován perlovcovým prstencem se stylizovanými květy ve cviklech v podobě trojic důlků vyplněných červenou barvou, položených na světle hnědém engobovém podkladu ( 2 kusy: $205 \times 205$ mm, hloubka 75 mm; obr. 4). Kompletně zachovaný asymetrický kus z nároží měl levou stranu s kruhovým medailonem mírně protáhlou a pravou s oválným redukovanou do obdélníka $(205 \times 225 \mathrm{~mm}$ a $205 \times 160 \mathrm{~mm}$, hloubka $130 \mathrm{~mm}$; obr. 3). Konkávní kusy se zbytky zlatého slídování na povrchu byly po obvodu lemovány nízkou vývalkovou lištou s hladkými miskami uprostřed a drobnými kosočtverci se dvěma křížky v rozích ( 2 kusy: $210 \times 210 \times 105 \mathrm{~mm}$; obr. 5). 


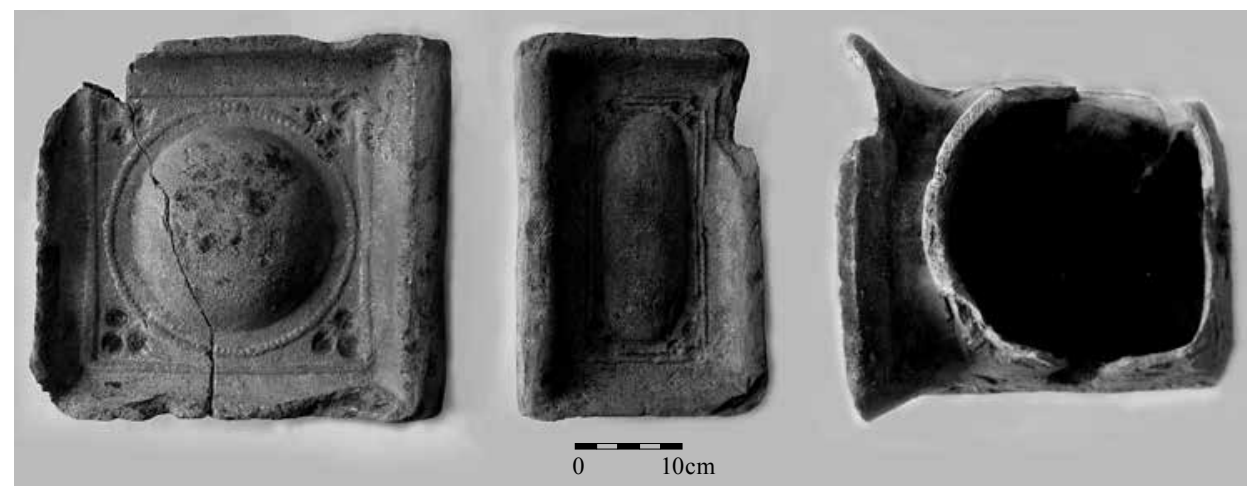

Obr. 3. Javorník - Jánský Vrch. Asymetrický rohový kachel s konvexními medailony. Foto M. Tymonová. Abb. 3. Javorník - Johannesberg. Asymmetrische Eckkachel mit konvexen Medaillons. Foto M. Tymonová.

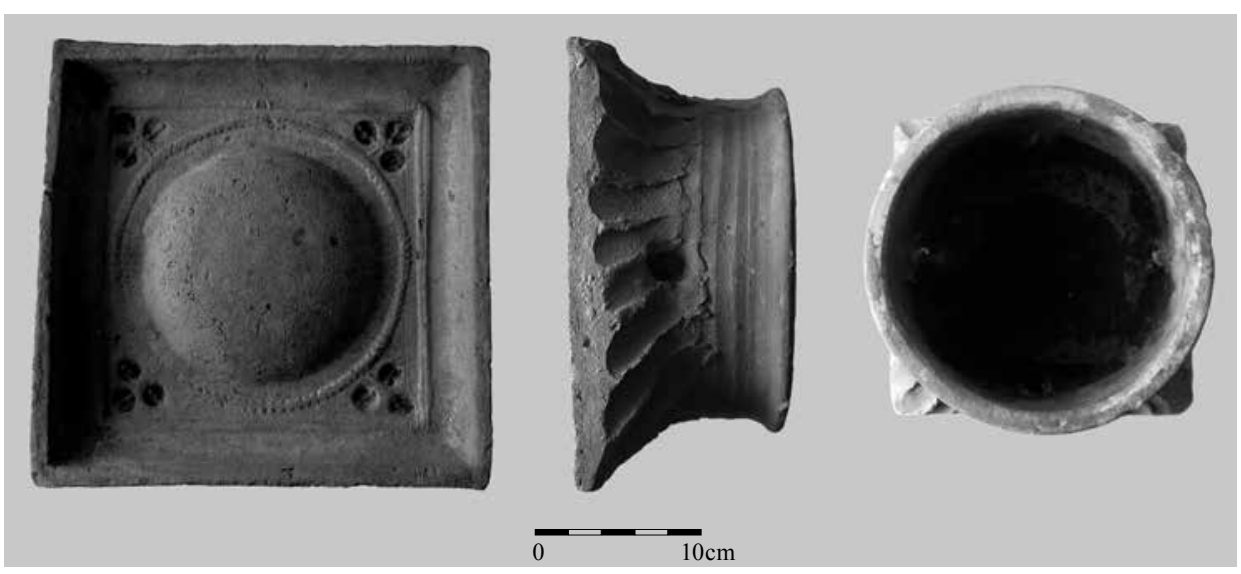

Obr. 4. Javorník - Jánský Vrch. Řádkový kachel s konvexním medailonem. Foto M. Tymonová. Abb. 4. Javorník - Johannesberg. Füllkachel mit konvexem Medaillon. Foto M. Tymonová.

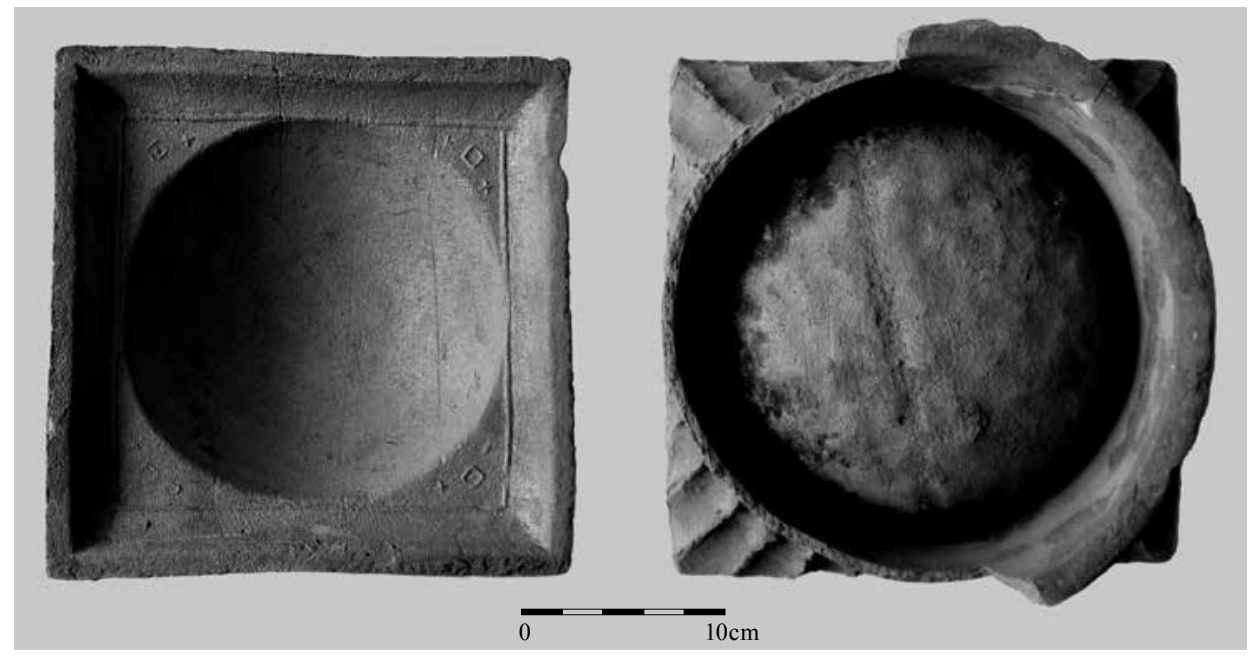

Obr. 5. Javorník - Jánský Vrch. Řádkový kachel s konkávním medailonem. Foto M. Tymonová. Abb. 5. Javorník - Johannesberg. Füllkachel mit konkavem Medaillon. Foto M. Tymonová. 


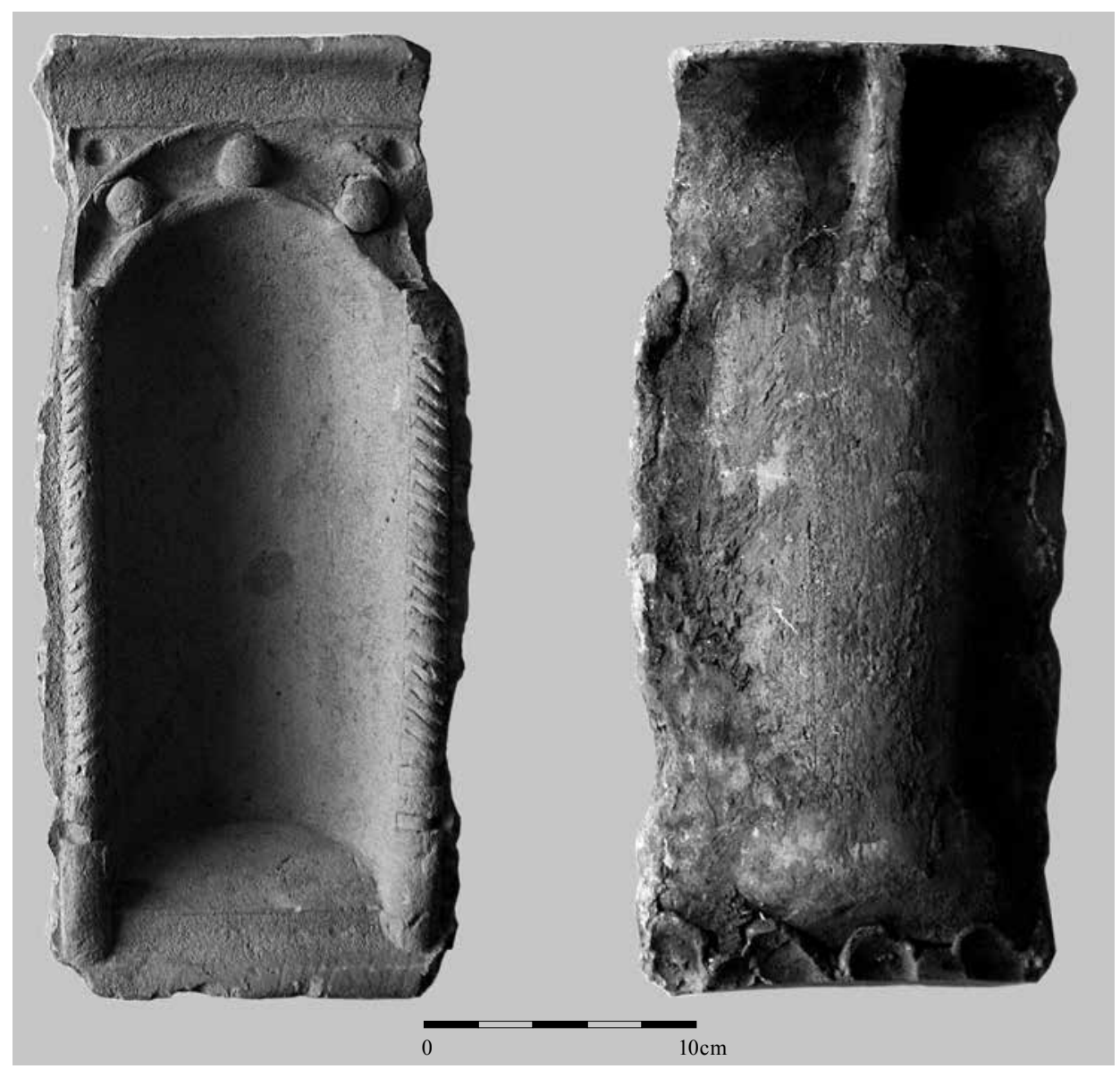

Obr. 6. Javorník - Jánský Vrch. Nikový kachel s tordovanými sloupky. Foto M. Tymonová. Abb. 6. Javorník - Johannesberg. Nischenkachel mit tordierten Säulen. Foto M. Tymonová.

Je otázkou, zda do sestavy náležel obdélný, nahoře půlkruhově ukončený nikový tvar se štíhlými, šikmo tordovanými sloupky po stranách $(315 \times 145 \mathrm{~mm}$, hloubka $52 \mathrm{~mm}$; obr. 6), opatřený na rubu svislým žebírkem a výraznými zamačkávanými důlky na spodním okraji (Loskotová 2008, 120, 136, kat. č. 442). Vrchní část kamnového korpusu tvořily římsové kachle s hladkým výžlabkem (4 kusy: $190 \times 280$ až 300 mm, hloubka 87 až 90 a 105 mm), jejichž uchycení ve stěně kamen fixovala dvojice záchytných otvorů na kratších stranách obdélné komory a šikmé záseky na vnější straně pláště (obr. 7). Do horní partie kamen byly pravděpodobně zabudovány $\mathrm{v}$ opačném uložení tak, aby na nich mohly spočívat římsové nástavce. Nelze však určit, zda byly zakomponovány do soklové či nástavcové partie, pouze kus s komorou vyplněnou kamnářskou mazanicí mohl být spíše pateční, poněvadž svou váhou zajištoval větší stabilitu otopného tělesa, a tudíž nezatěžoval stěny kamen (obr. 8). Tento konstrukční prvek se dle Jiřího Pajera rozšiřril v době, kdy se začaly snižovat stěny komor a nastupovaly mladší rámové typy $(1983,121)$.

Kromě inovací souvisejících s tepelnou funkcí kamen se nové prvky objevily i ve výzdobě, v níž se poprvé samostatně uplatnily plastické medailony, které kachlová tvorba převzala z renesanční architektury. Tento nový dekorativní prvek, jemuž se po výtvarné stránce nejvíce přibližují rozety, není domácího původu. Hladké miskovité útvary s florálními prvky v rozích svou jednoduchostí konvenovaly duchovnímu ideálu habánů, kteří k nám přicházeli z německy 


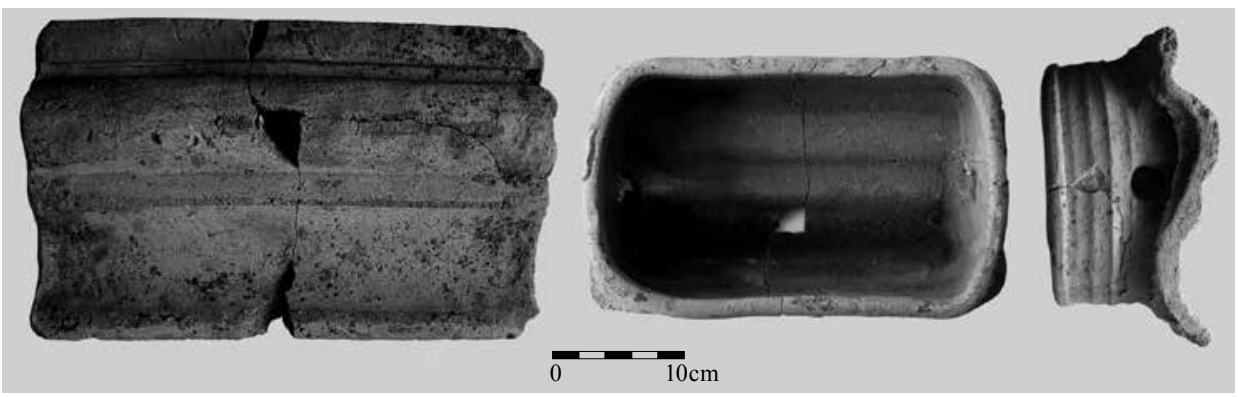

Obr. 7. Javorník - Jánský Vrch. Římsový kachel s hladkým výžlabkem. Foto M. Tymonová. Abb. 7. Javorník - Johannesberg. Gesimskachel mit glatter Hohlkehle. Foto M. Tymonová.

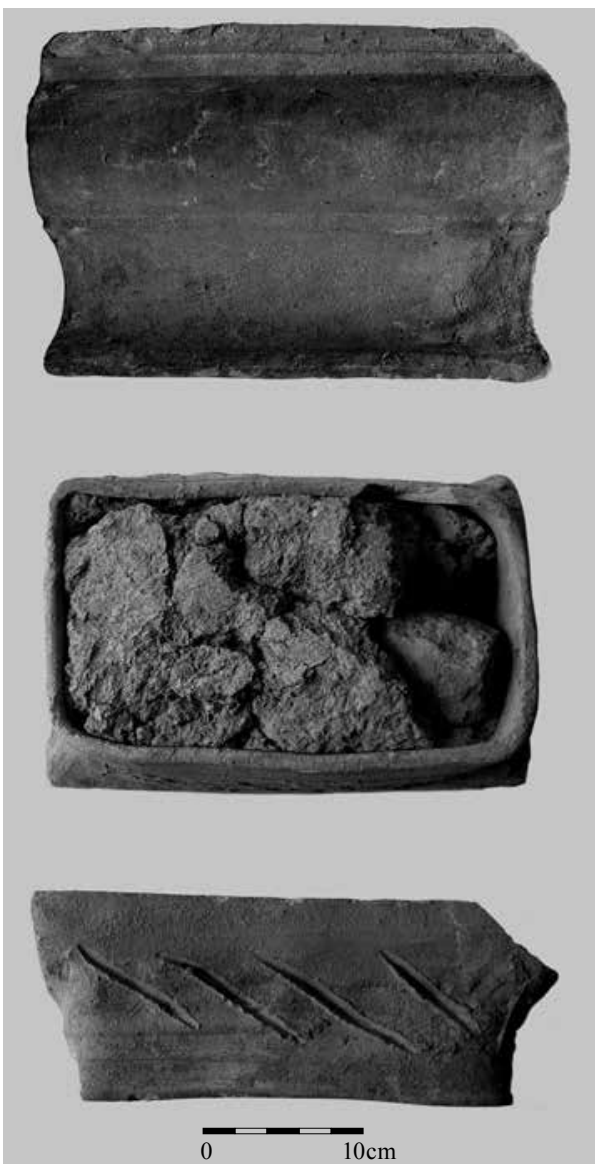

Obr. 8. Javorník - Jánský Vrch. Pateční kachel vyplněný kamnářskou mazanicí. Foto M. Tymonová.

Abb. 8. Javorník-Johannesberg. Mit Töpferlehm ausgeschmierte Fußkachel. Foto M. Tymonová. mluvících zemí a útočiště nalezli v nábožensky tolerantním prostředí Moravy. Nejprve se $\mathrm{v}$ roce 1526 usadili na mikulovském panství Leonharda z Lichtenštejna a později byli přijímáni na statcích Boskoviců, Žerotínů, pánů z Lipé nebo Kounic. Odmítnuti nebyli ani na církevním panství v Hustopečích, které patřilo starobrněnskému klášteru. $\mathrm{V}$ novém prostředí se díky své skromnosti a pracovitosti rychle adaptovali a prosluli jako schopní řemeslníci. Jejich vysoce kvalitní hrnčířské a kamnářské výrobky byly natolik žádané, že inspirovaly domácí výrobce, kteří kopírováním napodobovali původní předlohy i mimo oblasti osídlené novokřtěnci. Kamna s medailonovými a mozaikovými vzory se stala módní záležitostí a kolem poloviny 16 . věku začala postupně vytlačovat tradiční figurální nebo vegetabilní výzdobou (Zeman 1968, 33; Kalesný 1981, 24; Pajer 1983, 78, 103; 2006, 5-7; Pánek 1994, 250-251; Rozehnalová 2002, 25; Bartošková 2008, 6-9; Březíková 2009, 7-10). Vyznívání tohoto, do našich zemí importovaného, výzdobného stylu medailony z kachlových reliéfů zcela nevytěsnilo, nebot' v podobě vegetabilního orámování se na portrétních kachlích tzv. medailonového typu udržely do závěru třetí čtvrtiny 16 . století (Žegklitz 2006, 89, tam další literatura).

\section{Vyhodnocení nálezů}

Přesné analogie ke kachlům s popsaným technologicko-výzdobným rukopisem zatím publikovány nebyly. Vypouklé i zahloubené centrální misky uprostřed čtvercových ČVS se stylizovanými erbovními štítky nebo křížky v rozích byly spolu s rohovými variantami zjištěny v saské Mittweidě (Webersttraße 5), kde byla v roce 1996 prozkoumána jáma s destrukcí spojovanou s požárem města v roce 1551. Další nálezy jsou 
známy z rakouského Weiskirchenu u Judenburgu nebo polského Radomia či Bolesławce nad Prosną, kde byly datovány do let 1541-1559. Zeleně glazované kachle z druhé poloviny 16. století se našly na hradě Lauenstein v Durynsku, v Norimberku a také v Kolářské ulici v Opavě, kde se vyskytly zeleně a vínově glazované zlomky čtvercových stěn s miskou obkrouženou prožlabeným prstencem se stylizovanými květy nebo větévkami v rozích (Strauss 1940, 68, Taf. Abb. 4; 1966, 142-143, Taf. 76:3, 4; Żemigała 1987, 38-40, Fot. 37, tabl. IV:7-8; Krasnokutská 2005, 23, Tab. 11:2, 3; Olejnik 2010, 53; Hoffman 2013, 517, 527).

Exempláře s miskovitým zahloubením, rozšířené během druhé poloviny 16. století a ojediněle ještě na počátku 17. století, se v archeologických nálezech vyskytují častěji, a to jak v režné, tak i v glazované podobě, případně mají povrch přetažen tenkou vrstvičkou slídy (Pajer 1983, 104-106; 1999, 33; Hazlbauer-Špaček 1986, 157; Kubín 2004, 96; Loskotová 2009, 24). Známe je z řady jihomoravských „habánských“ lokalit (např. Mikulov - Brněnská ulice, Strážnice Grůska, Veselská ulice, Vacenovice aj.), kde se zpravidla nachází v doprovodu mladší vyznívající varianty s pěti misečkovitými zahloubeními (Pajer 1974, 178; 1983, 103-110, 120-130, obr. 44-45, 48; 1999, 33; Kubín 2004, 96; Loskotová 2008a, 154-155, kat. č. 511-512, 515; Holub-Jordánková-Loskotová 2009, 10). S habánskou produkcí jsou tyto tvary spojovány také na Slovensku, kam odcházeli novokřtěnci po vypovězení z Moravy v roce 1622 . Kromě varianty s jedním centrálním zahloubením (Šintava, Branč, Ostrý Kameň) se zde vyskytují i exempláře se čtyřmi nebo pěti a dokonce šesti miskami (Branč, Topolčany, Oponice), datované do konce 16. století (Bielich 2012, 203). Čtyři či pět medailonků měl i fragment ze zahrady janovického zámku na Rýmařovsku, nalezený v doprovodu luxusního čtvercového kusu s prázdným medailonem lemovaným listovitým věncem, jehož rohová varianta měla v obdélných polích elipsovité prohlubně. Kromě střepů z misek rámovaných negativním perlovcem se v rumištní vrstvě, datované do doby po roce 1586, vyskytly i mozaikové exempláře a kachle s dvojitými nikami, jaké jsou známy z hradu Lukova, Pražského hradu nebo kamen Hanse Elsessera z doby po roce 1557 ve cvikovském muzeu (Karel 1997, 59-60, 63; Brych 2004, 29; Loskotová 2008, 136, kat. č. 444).

Pozdně renesanční exempláře s bohatší rohovou výzdobou na čtvercových nebo obdélných ČVS, považovanou obecně za mladší, jsou doloženy z Brna - Husovy nebo Veselé ulice, Čelákovic - ulice Stankovského, zámku ve Frýdku a Hranic na Moravě, Chrudimi - Husovy ulice (odkud, podobně jako z Holešova - Přerovské ulice, pochází i kadluby), Louňovic pod Blaníkem, Nového Strašecí, Opavy - Krnovské, Ostrožné a Pekařské ulice, zámku Opočna, Prahy (Nové Město, Pražský hrad - Jiřské náměstí, Lobkovický palác, anonymní exempláře ve sbírkách Národního muzea), dále hradů Rábí nebo Točníku. Řada nálezů byla získána ze Starého města ve Vratislavi (ulice Więzenna, Igielna, Szewska atd.) a další akvizice uchovávají muzea v Hamburku nebo ve Štýrském Hradci aj. (Strauss 1940, 68, Taf. VI, Abb. 4; 1972, 130, Abb. 73:5; Pajer 1983, 154, obr. 510, 513-514; Brych-Stehlíková-Žegklitz 1990, 144-146, kat. č. 330-334; Dymek 1995, 38; Frolík, 2003, 71; Brych 2004, 202, 525-529; Pavlík-Vitanovský 2004, 304-305, 430, kat. č. 1203-1204, 1208-1213; Skružný-Špaček 2004, 253, 257, 268, kat. č. 35, 57-58; Krasnokutská 2005, 33, 51, 71, Tab. 27:6, 44:1, 51:3, 10; Blažková-Dubská 2007, 28-29, fig. 19:1, 2, 20:1, 2, tam další literatura; Loskotová 2008a, 142-143, 154, kat. č. 513-514, 158, 161, 524-524a, 525-525a). Nálezů je jistě daleko více především v německy mluvících zemích, avšak valná část nebyla zveřejněna nejen pro jejich četnost, ale i kvůli jejich výtvarné uniformitě, jež nepřitahuje takovou pozornost jako exkluzivní materiál s bohatou figurální výzdobou.

Interpretace těchto nálezů metodicky souvisí s otázkou jejich zakomponování do celkové koncepce kamen, kterou se již kdysi několikrát zabýval Jiří Pajer, jenž publikoval kresebnou rekonstrukci vytvořenou podle strážnických nálezů (1983, 106, 128-129, obr. 64). Plastické medailony přisoudil kamnům přechodného typu, zatímco nový typ spojil s mladšími mozaikovými kachly, rozšířenými ve druhé polovině 16. a na počátku 17. století. Nedávný nález kadlubu s letopočtem 1554 v inventáři pražské dílny Adama Špačka, činné v letech 1531-1572 v Truhlářské ulici, naznačuje, že oba výzdobné styly se vyvíjely paralelně (Žegklitz-Vitanovský-Zavřel 2009, 432, 434, 450, obr. 8). O hmotovou rekonstrukci kamen složených z medailonových a portrétních kachlů se později pokusila Kateřina Dymek na základě materiálu ze slezského zámku Wleń, 
jehož datování opřela o přestavbu v roce 1567 (Dymek 1995, 45, 89-90, 273, Tabl. XXXVI). Nejnovější představu o konstrukci kamnového tělesa publikoval Maxym Mackiewicz v souvislosti s vyhodnocením souboru z odpadní jámy v Komandorské ulici ve Vratislavi, v jejímž obsahu se kromě zeleně glazovaných řádkových kachlů s medailonovým zahloubením vyskytly také asymetrické rohové varianty a hladké výžlabkové římsy (Mackiewicz 2013, 446-447, Ryc. 2a-b, 4).

Medailonové kachle, rozšiřené před polovinou 16. století, představují módní kamnářské zboží cizího původu, které se od domácí „nehabánské“ produkce odlišuje jak po stránce technologické (konstrukce kamnových nároží, nové typy římsových kachlů, prř́chytná žebra, vyplňování mazanicí), tak výtvarné. Jiří Pajer tyto výrobky řadí $\mathrm{k}$ „novému vývojovému proudu“ produktů habánských dílen, jejichž počátky klade na základě rozboru strážnického materiálu do období let 1540-1560, přičemž předěl mezi pozdně středověkou a raně novověkou kachlovou produkcí vymezuje lety 1530-1550, kdy se objevují první kachle novověkého proudu s medailony a mozaikovými (tapetovými) vzory. Za nejstarší doklady pronikání nových forem považuje kachle s medailonovým zahloubením, které spojuje s počátky habánské keramické produkce na Moravě. Tomuto datování v zásadě odpovídá situace zjištěná v Dambořicích u Hodonína, kde podle Dany Menouškové zřetelný předěl mezi starší domácí výrobou (gotickou i renesanční) a novou importovanou tradicí způsobil příchod novokřtěnců v roce 1550. Jejich výrobní aktivity dokládají nálezy hrnčířských pecí s množstvím odpadu v Nové ulici (Pajer 1983, 100-106, 126; Loskotová 2008a, 143; Menoušková 2003, 561; 2003a, 174; 2004, 161-162).

Vezmeme-li v úvahu, že se originální kachle s medailony rozš́řily velice brzy a stejně rychle byly místními výrobci napodobovány, je možné, že i javornický soubor mohl vzniknout ještě před či kolem poloviny 16 . století. $\mathrm{K}$ přesnějšímu datování přispěl nálezový kontext, nebot' ze zásypu vlčí jámy byly vyzvednuty i dvě mince: $z$ hloubky $23 \mathrm{~cm}$ stř́ibrný krejcar braniborského markraběte Jiř́ího Bedřicha z roku 1563 a stříbrný haléř města Vratislavi z období vlády Vladislava Jagellonského († 1516) z úrovně $50 \mathrm{~cm}$ (Growka-Brachtl 1997, 24). Na základě této stratigrafické situace je zřejmé, že medailonové kachle jsou starší než rok 1563 a teprve v tomto roce, či nedlouho poté mohla být kamna rozebrána a vyhozena. Tento časový mezník, který se bohužel opírá pouze o nález jedné mince a nekryje se s výraznou stavební úpravou, posunuje vznik kachlů před polovinu století. Celkovou délku životnosti kachlového tělesa pak odhaduje Jiří Pajer, a stejně tak i Čeněk Pavlík a Michal Vitanovský, na zhruba 20-30 let (Pajer 1983, 82; Pavlík-Vitanovský 2004, 16). Naopak Hans Georg Stephan uvažuje nanejvýš o 10-15 letech, což by zbudování kamen přiblížilo k polovině století nebo těsně před ni (Stephan 1992, 73; Hoffmann 2013, 525). Druhý odhad se zdá být i z technického hlediska reálnější, protože kamna v plném provozu mohla stěží fungovat několik desítek let. Jejich kompletní výměna jistě nebyla levnou záležitostí, a proto se k nutným opravám spojeným s náhradou vadných segmentů používaly kachle vyrobené „do zálohy“ už při prvotní zakázce, anebo se vadné kusy nahrazovaly podle aktuální nabídky hrnčířské dílny. Na základě přání zákazníka se však mohly vyrobit kachle nové s požadovanými rozměry i výzdobou, což ovšem předpokládalo zhotovení nové formy. Ve větších dílnách se pro tento případ mohly kadluby skladovat, jak naznačilo nedávné zjištění téměř sedmi desítek kadlubů připisovaných výše zmíněné Špačkově výrobně. Tímto způsobem mohly být zajištěny reparace starších těles, kterých byly v hlavním městě jistě desítky až stovky. I když pro toto tvrzení nemáme žádné opodstatnění, přesto to mohl být jeden z důvodů, proč se některé motivy navzdory módním požadavkům vyráběly nezvykle dlouho (Žegklitz-Vitanovský-Zavřel 2009, 452). Pakliže odhlédneme od estetické stránky výsledku a zohledníme nízký počet jedinců, pak k reparaci javornických kamen mohly být využity i kachle s medailony. Tato možnost se však nezdá pravděpodobná, protože se v souboru vyskytují i rrímsové varianty. Jiné řešení hypoteticky nabízí kombinace portrétních a medailonových kachlů v jednom tělese, jak se o to pokusila při rekonstrukci kamen ze zámku Włeń Kateřina Dymek. Odlišné rozměry a tvary komor obou javornických celků však tuto možnost nepotvrzují.

S uvedenými nálezy se pojí také otázka původu kachlového materiálu, kterou při absenci přímých analogií lze řešit pouze hypoteticky. Jako potenciální výrobní středisko připadá v úvahu některé $\mathrm{z}$ větších center, $\mathrm{v}$ němž působili hrnčíři specializující se na produkci kamnářského 
zboží. Jedním z takových byla Opava, kde se kachle vyráběly v dílně v Krnovské ulici, která zásobovala město včetně některých hradních sídel (Cvilín?, Vartnov, Vikštejn) na Opavsku (Tymonová 2014, 161-167). V jejím inventáři shodné nálezy zjištěny nebyly, i když se zde zřejmě vyráběly vzpomenuté mladší medailonové varianty, nalezené na několika místech ve městě. Z dalších lokalit přichází v úvahu církevní střediska v Olomouci a Vratislavi, jejichž materie vykazuje obecně shodné rysy. Hlubší srovnání kachlových nálezů z obou měst však zatím není možné, protože zveřejněna byla pouze mizivá část a keramický materiál z Hrnčířské ulice Olomouci, kde byla zjištěna renesanční pec a několik kadlubů, ještě zpracován nebyl (Tymonová 2014, 158). V dolnoslezské metropoli byla existence hrnčířské dílny prokázána teprve nedávno, a to nálezem dvou matric v ulici Jana Evangelisty Purkyně s negativy polopostavy pod arkádou a sloupku nároží rohových kachlů (Piekalski-Wachowski 2010, 344, 347; Konczewski-LasotaPiekalski 2011, 320; Mackiewicz 2013, 448). Důležité však je, že pozitiv z druhé, výše uvedené formy se našel ve studni na parcele mezi Komandorskou a Pilsudského ulicí na Svídnickém předměstí, v níž byl kromě mladších variant se zahloubenými medailony identifikován i portrétní kachel s polopostavou urozeného muže pod arkádou (Mackiewicz 2013, 442, ryc. 1a), jehož zcela identický protějšek se vyskytl ve vlčí jámě v Javorníku (Menoušková 2008, 85, kat. č. 254). Rozměry obou se sice o několik centimetrů liší, což mohlo ovlivnit složení těsta a výpal, nicméně reliéf se shoduje i v detailech, a proto snad můžeme uvažovat o společném místě výroby obou kusů, nebo o existenci dvou forem zhotovených podle stejné předlohy. Tento poznatek se sice přímo netýká medailonových kachlů, avšak může naznačovat jeden ze směrů, odkud mohlo (ale také nemuselo) kachlové zboží do Javorníka přicházet. Podobné nálezy, jako je tento výjimečný prrípad, přispívají k osvětlení mechanismu šíření výzdobných motivů prostřednictvím výměny zboží nebo forem.

\section{Závěr}

Soubor medailonových kachlů z Javorníka představuje po stránce technologické i výzdobné hrubě modelovaný materiál $\mathrm{s}$ archaickými rysy, který sice habánské výrobky připomíná, avšak svým charakterem se od technicky dokonale propracovaných originálů podstatně liší. Rozdíly jsou patrné především ve tvaru komory, která bývá u původních kusů nízká, zešikmená, se specificky tvarovaným ústím vyhřívacího otvoru, jehož okraj bývá přehnutý a přitištěný. Někdy je i vodorovně prožlabený, takže vytváří jakési záchytné žebírko. Tyto konstrukční prvky jesenický soubor zjevně postrádá, a proto vzhledem k celkové morfologii a rustikální podobě patrně jde o napodobeniny vyrobené podle habánských vzorů. Horní hranici vzniku této kolekce určuje mince z roku 1563 a spodní období před či kolem poloviny 16. století, kdy na biskupském stolci úřadoval Baltazar z Promnic, jehož zásluhou se Javorník stal opět centrem jesenické části panství. S jeho osobou snad lze spojit vybavování hradních interiérů kachlovými kamny, k jejichž odstranění došlo rok po nástupu nového biskupa Kašpara z Lohova.

\section{Literatura}

BARTOŠKOVÁ, S., 2008: Habáni v Dambořicích. Rkp. nepubl. bakalářské práce na PaedF MU Brno, vedoucí práce doc. PhDr. B. Klíma, CSc., Brno.

BIELICH, M., 2012: Nálezy neskororenesančných kachlíc z Oponického hradu (16.-17. storočie), Acta Historica Neosoliensia 15, 200-209.

BLAŽKOVÁ-DUBSKÁ, G., 2007: House of thearmoury scribe at Prague Kastle - Dům zbrojního písaře na Pražském hradě - Das Haus des Waffenschreibers auf der Prager Burg, Studies in Post-Medieval Archaeology 2, 9-42.

BRACHTL, Z., 1997: Javorník (okr. Šumperk). Zámek Jánský Vrch, PV 1993-1994, 202.

- 1997a: Renesanční kachel s biblickým námětem z javornického zámku, Communio 8-9, 127-128.

- 1998: Zjišt’ovací výzkum na zámku Jánský Vrch v Javorníku, okres Jeseník, Badania archeologizcne na Górnym Śłąsku i ziemiach pogranicznych w 1995 roku, 134-136. 
- 1998a: Komorový kachel s heraldickým motivem ze Žulové a Javorníku, Informační zpravodaj. ČAS pobočka pro severní Moravu a Slezsko, srpen, 93-95.

- 1999: Javorník (okr. Jeseník). Zámek Jánský Vrch, PV 39 (1995-1996), 407-408.

- 1999a: Javorník (okr. Jeseník). Zámek Jánský Vrch, PV 40 (1997-1998), 328-329.

- 1999b: Hesla č. 128-135. In: Od gotiky k renesanci. Výtvarná kultura Moravy a Slezska 1400-1550. Svazek IV. Opava (Chamonikola, K., ed.), 229-231. Brno.

- 2000: Druhá etapa zjišt’ovacího výzkumu na zámku v Javorníku, okres Jeseník, Badania archeologizcne na Górnym Śłąsku i ziemiach pogranicznych w 1996 roku, 159-161.

BRYCH, V., 2004: Kachle doby gotické, renesanční a raně barokní. Výběrový katalog Národního muzea v Praze. Praha.

BRYCH, V.-STEHLÍKOVÁ, D.-ŽEGKLITZ, J., 1990: Pražské kachle doby gotické a renesanční. Katalog výstavy. Praha.

BŘEZÍKOVÁ, M., 2009: Listy Jana Diviše ze Žerotína novokřtěncům (Kritická edice vybraných listů z kopiáře německé korespondence Jana Diviše ze Žerotína). Rkp. nepubl. magisterské diplomové práce na FF MU Brno, ved. práce doc. PhDr. Vladimír Vašků, CSc.

DEHNEROVÁ, H., 2011: Pozdně gotické kachle z Javorníka (okr. Jeseník), Sborník Národního památkového ústavu územního odborného pracoviště v Olomouci, 29-36.

DEHNEROVÁ, H.-ŠLÉZAR, P., 2012: Archeologický atlas SZ Jánský Vrch, Javorník. Olomouc.

DYMEK, K., 1995: Średinowieczne i renesansowe kafle śłaskie. Wrocław.

FROLÍK, J., 2003: Kachle Chrudimska. Sbírky Regionálního muzea v Chrudimi. Chrudim.

FUKALA, R., 1997: Role Jana Jiřího Krnovského ve stavovských hnutích. In: Opera Facultatis philosphicae et rerum naturalium Universitatis Silesianae Opaviensis. Studia historica - Monographiae 1. Opava.

- 2005: Hohenzollernové v evropské politice 16. století. Praha.

GROWKA, K.-BRACHTL, Z., 1997: Nález mincí na Jánském Vrchu, Numismatik 3, 24.

HAZLBAUER, Z.-ŠPAČEK, J., 1986: Poznámky k výrobě reliéfních renesančních kachlů s přihlédnutím k nálezům ve stř̌edním Polabí, ČNM CLV, 146-166.

HOFFMANN, Y., 2013: Ein Fundkomplex spätgotischer Ofenkacheln aus Mittweida, Arbeits- und Forschungsberichte zur Sächsischen Bodendenkmalpflege 53/54 (2011/12), 517-531.

HOLUB, P.-JORDÁNKOVÁ, H.-LOSKOTOVÁ, I., 2009: Early Modern period Brno stove tiles with a mosaic (tapestry) pattern - Kachle raně novověkého Brna s mozaikovým (tapetovým) vzorem - Kacheln aus dem frühneuzeitlichen Brünn mit Mosaik-bzw. Tapetenmuster, Studies in Post-Medieval Archaeology 3, 273-302.

CHROBAK, P.-SZYMKOWICZ, P., 2007: Historia księstwa nyskiego zabytkami pisana. In: Zabytki Euroregionu Pradziad - dziedzictwo historyczne pogranicza nysko-jesenickiego, 4-38. Prudnik.

KALESNÝ, F., 1981: Habáni na Slovensku. Bratislava.

KAREL, J., 1997: Renesanční nález v Janovicích, Střední Morava 5, 58-69.

KAŠPÁRKOVÁ, S.-PEŘINOVÁ, I.-VÍTEK, T., 1995: Jánský Vrch. Stavebně-historický průzkum hradu a zámku v Javorníku, díl 1. Rkp. ulož. v archivu NPÚ ÚOP v Olomouci, č. 52.

KONCZEWSKI, P.-LASOTA, C.-PIEKALSKI, J., 2011: Przedmieście Świdnickie we Wrocławiu w świetle badań wykopaliskowych na posesjach przy ulicach Józefa Piłsudskiego 69-73, Komandorskiej 5-11 i Wojciecha Bogusławskiego 16, Śłaskie Sprawozdania Archeologiczne 53, 305-324.

KOUŘIL, P., 2009: Hrad Javorník: březen 1428 - září 1434 (příspěvek k poznání hmotné kultury doby husitské ve Slezsku) - The Castle of Javorník: March 1434 - September 1438. Contribution to the History of Material Culture in the Hussite Period in Silesia, ČSZM B 58, 221-235.

KOUŘIL, P.-PRIX, D.-WIHODA, M., 1997: Městské hrady v českém Slezsku - Stadtburgen in Böhmisch-Schlesien, AH 22, 249-272.

- 2000: Hrady českého Slezska. Brno - Opava.

KOUŘIL, P.-WIHODA, M., 1997: Středověké fortifikace a „Jesenická stezka“ v údolí Černé Opavy Mittelalterliche Befestigungen und die „Gesenker Strasse“ im Tal der Schwarzen Oppa, AH 23, 111-131.

-2001: Wüstehubové. Ďáblovo plémě nebo tvůrcové kulturní krajiny? Die Adelsfamilie Wüstehube. Teufelsgeschlecht oder die Schöpfer einer Kulturlandschaft?, ČSZM B 50, 205-217.

KRASNOKUTSKÁ, T., 2005: Středověké a novověké kachle z Opavy. Katalog nálezů z archeologických výzkumů. Archaeologiae Regionalis Fontes 8. Olomouc.

KUBEŠOVÁ, I.-RICHTEROVÁ, H., 1999: Jánský Vrch. In: Od gotiky k renesanci. Výtvarná kultura Moravy a Slezska 1400-1550. Svazek IV. Opava (Chamonikola, K., ed.), 58-61. Brno.

KUBÍN, P., 2004: Zpráva o záchranném archeologickém výzkumu na Brněnské ulici v Mikulově, Regio M: sborník regionálního muzea v Mikulově, 87-102. 
LOSKOTOVÁ, I., 2008: Architektonické motivy. In: Krása, která hřeje. Výběrový katalog gotických a renesančních kachlů Moravy a Slezska - Schönheit, die wärmt. Gotische und renessainzeitliche Kacheln aus Mähren und Schlesien (Menoušková, D.-Měřínský, Z., edd.), 117-137. Uherské Hradiště.

- 2008a: Ornament na kachlích. In: Krása, která hřeje. Výběrový katalog gotických a renesančních kachlů Moravy a Slezska - Schönheit, die wärmt. Gotische und renessainzeitliche Kacheln aus Mähren und Schlesien (Menoušková, D.-Měřínský, Z., edd.), 139-155. Uherské Hradiště.

- 2009: Ornament v kachlovém reliéfu středověkého a raně novověkého Brna. In: Ornament - oděv - šperk. Archaické projevy materiální kultury. Etnologické studie 5, 9-27. Brno.

MACKIEWICZ, M., 2013: Wczesnonowożytne kafle piecowe z Przedmieścia Świdnickiego we Wrocławiu - Post medieval stove tiles from Świdnica Suburb in Wrocław, Śłaskie Sprawozdania Archeologiczne LV, 439-450.

MAZUR, D., 2014: Kafle piecowe jako źródło materialne i ikonograficzne. Znaczenie kafli w rekonstrukcji materialnych i niematerialnych aspektów życia codziennego dawnych społeczeństw - Ofenkacheln als materielle und okonographische Quelle. Die Bedeutung von Kacheln bei der Rekontruktion von materiellen und immateriellen Aspekten des Alltags vergangener Gesellschaften, AH 39, 177-203.

MENOUŠKOVÁ, D., 2003: Předhabánská kachlová produkce z Dambořic (okr. Hodonín). Unikátní série renesančních komorových kachlů a sekundárního kadlubu - Kachelproduktion aus Dambořice (Bez. Hodonín) vor dem Habanerfayencen. Einzigartige Kollektion von Renaissancekacheln und einer Sekundärform, AH 28, 561-574.

- 2003a: Portrétní a žánrové kachle z Dambořic. Renesanční horizont dambořické kamnářské produkce Portrait and Genre Stove Tiles from Dambořice - Renaissance Period Production of the Dambořice Stove Fitting Workshops, Slovácko XLV, 173-208.

- 2004: Nefigurální renesanční kachle z Dambořic - Nichtfigurale Renaissancekacheln aus Dambořice, Slovácko XLVI, 161-181.

- 2008: Portrétní kachle. In: Krása, která hřeje. Výběrový katalog gotických a renesančních kachlů Moravy a Slezska - Schönheit, die wärmt. Gotische und renessainzeitliche Kacheln aus Mähren und Schlesien (Menoušková, D.-Měřínský, Z., edd.), 73-88. Uherské Hradiště.

MYSLIVEČKOVÁ, H., 2011: Pamětní erbovní deska vratislavského biskupa Jana Thurza, Javorník, zámek Jánský Vrch (heslo A2.7.1 a 2). In: Pamět' Slezska - památky a pamětové instituce českého Slezska v 16. až 19. století, 37-38. Opava.

OLEJNIK, J., 2010: Kafle z zamku radomskiego - Stove tiles from the castle of Radom, Folia Archaeologica $27,49-75$.

PAJER, J., 1974: K metodice hodnocení lidové keramiky z archeologických nálezů (Na základě strážnických nálezů) - On the methods of evaluating Folk Ceramics Found at archaeological Sites (The Findings of Strážnice), Národopisné aktuality 3, 169-184.

- 1983: Počátky novověké keramiky ve Strážnici. Strážnice.

- 1999: Novokřtěnci ve Vacenovicích, Slovácko XLI, 31-54.

- 2006: Studie o novokřtěncích. Strážnice.

PAVLÍK, Č.-VITANOVSKÝ, M., 2004: Encyklopedie kachlů v Čechách, na Moravě a ve Slezsku. Ikonografický atlas reliéfů na kachlích gotiky a renesance. Praha.

PÁNEK, J., 1994: Moravští Novokřtěnci (Společenské a politické postavení předbělohorských heretiků, sociálních reformistů a pacifistů), ČCH 92, $242-255$.

PIEKALSKI, J.-WACHOWSKI, K., 2010: Przełom średniowiecza i nowożytności w miastach śłąskich, Śłąskie Sprawozdania Archeologiczne 52, 341-364.

ROZEHNALOVÁ, J., 2002: Gabrielité na jižní Moravě, čili novokřtěnci, jak je neznáme, Religio X, 25-44.

RYCHLÝ, M., 1999: Archeologické nálezy v odpadním systému zámku Jánský Vrch v Javorníku, Informační zpravodaj ČAS - pobočky pro sev. Moravu a Slezsko, 92-96.

- 2000: Archeologické výzkumy Vlastivědné muzejní společnosti v r. 1999. In: Jesenicko. Vlastivědný sborník, sv. 1, 29-30. Jeseník.

- 2003: Archeologické střípky z Jesenicka. In: Jesenicko. Vlastivědný sborník, sv. 4, 45-46. Jeseník.

RYCHLÝ, M.-KOLÁŘ, F., 2002: Výsledky archeologického výzkumu na Jánském Vrchu. In: Jesenicko. Vlastivědný sborník, sv. 3, 44-46. Jeseník.

SKRUŽNÝ, L.-ŠPAČEK, J., 2004: K vybraným motivům středověkých kachlů ze sbírek Městského muzea v Čelákovicích. Čelákovice.

SETTARI, O., 1993: Zámek Jánský Vrch a město Javorník v minulosti (Příspěvek k hudební topografii Slezska) - The chateau Jánský Vrch the town Javorník in the past (Contribution to the music history of Silesia), SPFFBU H 27-28, 45-53. 
STEPHAN, H. G., 1992: Keramik der Renaissance im Oberweserraum und an der unteren Werra. Beitrage der Archaologie zur Erforschung der Sachkultur der frühen Neuzeit. Zeitschrift für Archäologie des Mittelalters, Beiheft 7. Köln.

STRAUSS, K., 1940: Kacheln und Ofen der Steiermark. Studien zur Geschichte der Keramik in der Ostmark. Beiträge zur Kunstgeschichte Steiermarks and Kärtens. Graz.

- 1972: Die Kachelkunst des 15. und 16. Jahrhunderts in Deutschland, Österreich, Schweiz und Skandinavien. II. Teil (Neue Folge). Basel.

- 1966: Die Kachelkunst des 15. bis 16. Jahrhunderts in Deutschland, Österreich und der Schweiz I. Strassburg.

ŠLÉZAR, P., 2003: Javorník (okr. Jeseník). Zámek Jánský Vrch, PV 44, 254-255.

TYMONOVÁ, M., 2009: Středověké reliéfní kachle jako pramen hmotné kultury (Slezsko) - Mittelalterliche Reliefkacheln als Quelle der Sachkultur (Schlesien), AH 34, 209-223.

- 2011: Gotické a renesanční kachle ze slezských hradů - Gothic and Renaissance Tiles from Silesian Castles. Rkp. nepubl. disertační práce na ÚAM FF MU, Brno, díl I.-III., vedoucí práce doc. PhDr. P. Kouřil, CSc.

- 2014: Výroba kamnářské keramiky v českých zemích a dílna v Opavě - Belege für die Herstellung von Ofenkeramik in den Ländern Böhmens und eine Werkstatt in Opava, AH 39, 155-175.

VÍTEK, T., 2009: K stavebně-historickému průzkumu fasád zámku Jánský Vrch, Sborník NPÚ ÚOP v Ostravě, 134-141.

- 2010: Výsledky stavebně-historického průzkumu fasád zámku Jánský Vrch (okres Jeseník), ZPP 70, 212-218.

WIHODA, M., 1998: Geneze městského zrrízení na Moravě jako zakladatelské dílo markraběte Vladislava Jindřicha? - Die Genesis der Stadtverfassung in Mähren als Gründunsvorhaben des Markgrafs Vladislav Jindřich?, SPFFBU C 45, 21-35.

- 2010: Výsledky stavebně-historického průzkumu fasád zámku Jánský Vrch (okres Jeseník), ZPP 70, 212-218.

VOJKOVSKÝ, R., 2008: Jánský Vrch. Zámek v Javorníku ve Slezsku. Dobrá.

ZEMAN, J. K., 1968: The Anabaptists and the Czech Brethren in Moravia 1526-1628. A. Study of Origins and Contact. Haag.

ZUBER, R., 1966: Jesenicko v období feudalismu do roku 1948. Ostrava.

- 1972: Osídlení Jesenicka do počátku 15. století. Opava.

ŽEGKLITZ, J., 2006: Renesanční portrétní kachle z hrnčířské dílny Adama Špačka v Truhlářské ulici v Praze - Renaissance portrait stove tiles from the potery workshop of Adam Špaček in Truhlářská Street, Prague, AR LVIII, 78-116.

ŽEGKLITZ, J.-VITANOVSKÝ, M.-ZAVŘEL, J., 2009: Soubor kachlových forem z pražské hrnčířské dílny Adama Špačka a její kachlová produkce v letech 1531-1572 - An assemblage of stove tile moulds from the Prague pottery workshop of Adanm Špaček and the tile production of this facility in the years 1531-1572, AR LXI, 427-466.

ŻEMIGALA, M., 1987: Ogrzewanie piecowe na zamku w Bolesławcu nad Prosą w XIV-XVII. w. Wrocław Warszawa - Kraków - Łodź.

\section{Zusammenfassung}

\section{Die Medaillonkacheln aus Javorník}

Der vorliegende Beitrag erörtert eine Gruppe von Medaillonkacheln von Schloss Johannesberg (Abb. 1), die von Zdeněk Brachtl in den Jahren 1996 und 1997 aus den Aufschüttungen der im Bereich der sogenannten Wolfsgrube unter dem Torturm im nordöstlichen Teil des Objektes gelegenen Sondiergrabung Nr. IX/96 (2,7×4,2 m, Tiefe 4,3-5 m) gehoben wurde (Abb. 2). In der einmaligen, durch Münzen datierten Bauschuttaufschüttung wurden drei zeitlich gut unterscheidbare Fundkomplexe entdeckt.

Der älteste, spätgotische Komplex von Ende 15. und Anfang 16. Jahrhundert bestand aus Kacheln mit kegelförmigen und halbzylindrigen Rümpfen und einer reichen Reliefverzierung (religiöse, heraldische, ornamentale und architektonische Motive). Den zweiten, aus der ersten Hälfte des 16. Jahrhunderts stammenden Komplex bildeten Kacheln mit leicht konischen Rümp- 
fen (Tiefe $100 \mathrm{~mm}$ ) und einer quadratischen, mit den Porträts von Edelmännern und -frauen in einer Renaissancarchitektur verzierten Platte.

Zur dritten, sich von den vorhergehenden hinsichtlich Technologie, Morphologie und Verzierung unterscheidenden Gruppe zählten Medaillonkacheln, die bei uns erstmals um Mitte des 16. Jahrhunderts in der Umgebung der mährischen Habaner-Werkstätten auftauchten. Diese Erzeugnisse waren durch fünf Exemplare vertreten, deren quadratische Platten zentral angeordnete konvexe (Abb. 3, 4) und konkave (Abb. 5) Schüsseln aufwiesen, die mit dem Rumpf durch fächerartige Fingereindrücke verbunden waren. Es ist fraglich, ob die rechteckige, oben halbkreisförmig abgeschlossene Nischenform mit den schlanken Säulen an den Seiten und der senkrechten Rippe auf der Rückseite (Abb. 6) ebenfalls zu dieser Gruppe gehörte. Im oberen Teil des Ofenkorpus waren wahrscheinlich Gesimskacheln mit glatter Hohlkehle so in umgekehrter Lage eingebaut, damit Zieraufsätze auf ihnen liegen konnten (Abb. 7). Der untere Teil des Sockels wurde durch eine Fußkachel befestigt, die mit Töpferlehm ausgeschmiert war (Abb. 8).

Von technologischer Seite her und auch was die Verzierung anbelangt handelt es sich um ein Material, das an Habaner Erzeugnisse erinnert, obwohl es sich seinem Charakter nach wesentlich von den qualitativ besseren Originalen unterscheidet, und zwar durch die Form des Rumpfs und die Ausformung der Kachelhalsrandes. Hinsichtlich seiner gesamten Morphologie und rustikalen Form handelt es sich offenbar um Nachahmungen, die von heimischen Töpfern nach den Habaner Vorbildern hergestellt worden waren. Die obere Entstehungsgrenze dieser Kollektion wird durch eine 1563 geprägte Münze bestimmt (Silberkreuzer des brandenburgischen Markgrafen Georg Friedrich). Die Untergrenze dann vor oder um Mitte des 16. Jahrhunderts, als Balthasar von Promnitz den Bischofsstuhl bekleidete, durch dessen Verdienst Javorník wieder Zentrum der Grundherrschaft wurde. Mit seiner Person lässt sich wahrscheinlich auch die Ausstattung der Innenräume mit Kachelöfen in Verbindung bringen, die dann ein Jahr nachdem der neue Bischof Kaspar von Logau sein Amt übernommen hatte wieder entfernt wurden.

PhDr. et PhDr. Markéta Tymonová, Ph.D., Ústav archeologie Filozoficko-přírodovědecké fakulty Slezské univerzity v Opavě, 74601 Opava, Česká republika, marketa.tymonova@fpf.slu.cz 
